\title{
W POSZUKIWANIU TOŻSAMOŚCI WSPÓŁCZESNEJ FILOZOFII PRZYRODY
}

\begin{abstract}
Streszczenie. W artykule podjęto kwestię dotyczącą tożsamości filozofii przyrody w kontekście trzech współcześnie wymienianych charakterystycznych cech tej dyscypliny, a mianowicie jej różnorodności metodologicznej, interdyscyplinarności oraz swoistej dynamiki rozwojowej. Analizowane są zagrożenia dla tożsamości filozofii przyrody, wynikające z takiego zestawu cech, w szczególności z różnorodności metodologicznej filozofii przyrody. Jednocześnie podjęto próbę obrony wymienionych cech jako powodujących nie tylko zagrożenia, ale również (paradoksalnie) wzmacniających tożsamość filozofii przyrody. Całość analiz odnosi się do metafilozoficznej charakterystyki dziedziny filozofii.
\end{abstract}

Słowa kluczowe: filozofia; filozofia przyrody; metafilozofia; metodologia; interdyscyplinarność

1. Wstęp. 2. Metafilozoficzny ogląd współczesnej filozofii przyrody. 3. Niejednorodność metodologiczna filozofii przyrody. 4. Interdyscyplinarność filozofii przyrody. 5. Dynamika rozwojowa filozofii przyrody. 6. Zakończenie.

\section{WSTĘP}

Wśród różnych fetyszy, jakie funkcjonują w kulturze filozoficznej pierwszych dwóch dekad XXI wieku, filozofia przyrody zajmuje (przynajmniej w środowisku polskiej filozofii) poczesne miejsce. Ta parafraza słów Stanisława Kamińskiego (Kamiński 1981), który w podobnym tonie wypowiadał się na temat nauki i techniki, wydaje się dobrze oddawać zainteresowanie, ale również i kontrowersje, pojawiające się w związku z tą dyscypliną filozofii. Rozmaitość podejść $\mathrm{w}$ rozumieniu przedmiotu, zadań i metod stosowanych w filozofii przyrody domaga się choćby próby ich syntetycznego ujęcia i scharakteryzowania, podobnie jak uczynił to m.in. S. Kamiński w stosunku 
do nauki. Chodzi zatem o metafilozoficzną charakterystykę tej dyscypliny filozofii. Punktem wyjścia i osią rozważań prowadzonych $\mathrm{w}$ niniejszym artykule jest jedna $\mathrm{z}$ takich prób. Jednocześnie w zaproponowanej charakterystyce współczesnej filozofii przyrody pojawiają się pewne trudności, które mogą zagrażać tożsamości filozofii przyrody i tym samym stawiać pod znakiem zapytania możliwość jej dalszego istnienia. Choć w klasycznych już dziś opracowaniach dotyczących filozofii przyrody (np. Melsen 1963) jako źródło „kłopotów" tej dyscypliny podawany był np. rozwój nauk przyrodniczych i postęp poznawczy dokonujący się dzięki nim, to źródłem owych trudności wydają się być właśnie metafilozoficzne cechy charakterystyczne dla współczesnej filozofii przyrody. W związku z tym $\mathrm{w}$ artykule przeprowadzone zostaną analizy wyróżnionych cech charakterystycznych filozofii przyrody pod kątem ich wzajemnych oddziaływań, jak również ich relacji do metafilozoficznych cech całej dziedziny filozofii. Celem artykułu jest próba odnalezienia, wskazania i uzasadnienia tożsamości filozofii przyrody w oparciu o jej wyróżnione cechy charakterystyczne.

\section{METAFILOZOFICZNY OGLĄD WSPÓŁCZESNEJ FILOZOFII PRZYRODY}

Wielka debata w środowisku polskich filozofów na temat tego, czym jest filozofia przyrody oraz sposobów jej uprawiania miała miejsce w trakcie VII Polskiego Zjazdu Filozoficznego, który odbył się w Szczecinie we wrześniu 2004 roku11. Głównym pytaniem debaty było: Komu i po co potrzebna jest dzis filozofia przyrody? Józef Zon we Wprowadzeniu do debaty (Zon 2005) stwierdza, że tak postawione pytanie miało na celu skierowanie uwagi na to, jaką rolę spełnia,

1 Teksty poszczególnych wystąpień oraz wypowiedzi, zebrane już po zakończeniu Zjazdu, zostały opublikowane w dwóch numerach Roczników Filozoficznych: Komu i po co potrzebna jest dziś filozofia przyrody? Punkty widzenia dyskutowane podczas VII Zjazdu Polskiego Towarzystwa Filozoficznego w Szczecinie, 17 września 2004 roku oraz wypowiedzi zebrane po Zjeździe, część 1 (2005) i część 2 (2006). 
może spełniać lub powinna spełniać filozofia przyrody. Założeniem dyskusji było zaś to, że filozofia przyrody istnieje i jest dyscypliną filozofii, która w pełni zasługuje na to miano². „Wyróżnia się spośród innych działów filozofii m.in. tym, że będąc uwrażliwiona na pytania o naturze filozoficznej i nawiązując do problemów filozofii, zajmuje się ożywionym i nieożywionym kosmosem, pozostając w ścisłym kontakcie z problematyką i osiągnięciami nauk przyrodniczych" (Zon 2005, 406).

W toku dyskusji okazało się, że różnice w określaniu ról, jakie może pełnić filozofia przyrody, a także wskazywanie mniej lub bardziej bezpośrednich korzyści (lub ich braku) płynących z rezultatów pracy filozofa przyrody (Bugajak 2006) wiążą się z odmiennością przyjmowanych koncepcji i sposobów uprawiania tej dyscypliny filozoficznej (Lemańska 2006). Część osób biorących udział w dyskusji skupiła się niemal wyłącznie na próbach określania charakterystyki filozofii przyrody (np. Krajewski 2005). Można zatem uznać, że przywołana dyskusja stanowiła kontynuację wcześniejszych debat na temat statusu metodologicznego filozofii przyrody. Ich omówienie można znaleźć m.in. w pracach Anny Lemańskiej (1998), Zygmunta Hajduka (2004), Michała Hellera (2004)3. Od czasu wspomnianego Zjazdu Filozoficznego „krzywa dyskusji” nieco opadła (Heller 2005), niemniej co kilka lat pojawiają się prace, które starają się zaprezentować aktualny stan badań w tej dyscyplinie filozofii. Można przywołać m.in.: Philosophy of Nature Today (2009), Filozofia przyrody wspótcześnie (2010), Filozofia przyrody - dzis (2011), Filozofia przyrody (2013), czy Encyklopedia filozofii przyrody (2016). Warto również

2 Przyjmuję następujące rozróżnienie: filozofia przyrody jest jedną z dyscyplin, jednym z działów filozofii, obok metafizyki, teorii poznania, etyki, logiki, historii filozofii, itd. Natomiast filozofia jest jedną z dziedzin wiedzy ludzkiej. Bardziej rozbudowane uporządkowanie struktury metodologicznej dziedzin wiedzy można znaleźć u Stanisława Kamińskiego (Kamiński 1981).

3 Przywołani autorzy wzięli również udział w omawianej debacie (Lemańska 2006; Hajduk 2005; Heller 2005). 
wspomnieć o pracy Oblicza filozofii w nauce (2017), która wpisuje się w przywołaną wyżej definicję filozofii przyrody, jaką zaproponował Józef Zon (Zon 2005). Do tego można dołączyć szereg opracowań o charakterze historycznym, co jest zgodne $\mathrm{z}$ wysuwanymi przez niektórych badaczy postulatami dotyczącymi charakteru dociekań prowadzonych w ramach filozofii przyrody (Roskal 2006). Można także przywołać opracowania monograficzne prezentujące sylwetki wybitnych polskich filozofów przyrody, m.in. Piotra Lenartowicza (Bremer i in. 2019), Kazimierza Kłósaka (Lemańska i in. 2020), Kazimierza Kloskowskiego (Bugajak i in. 2019). Należy wziąć także pod uwagę artykuły poświęcone dorobkowi filozoficzno-przyrodniczemu bądź to całych środowisk i szkół filozoficznych (np. Lubański 2005a; Heller, Mączka 2006; Heller i in. 2007a; 2007b; 2007c; Grygiel 2012; Mączka i in. 2012; Skoczny 2012; Polak 2016), bądź też poszczególnych ich przedstawicieli (np. Hajduk 2006; Łukomski 2006; Heller, Mączka 2010; Heller 2011; Heller, Mączka 2011; Śleziński 2016; Trombik 2018) i wreszcie opracowania ukazujące znaczenie dorobku przedstawicieli nauk przyrodniczych dla problematyki filozofii przyrody (np. Grygiel 2014; 2021; Grzanka 2020; Mazurek 2021).

W świetle powyższego aktualne pozostaje pytanie o to, jaki jest metafilozoficzny ogląd współczesnej filozofii przyrody. Można zgodzić się z Andrzejem Łukasikiem, który wskazuje metodologiczną niejednorodność filozofii przyrody jako na jedną z głównych jej cech. „(...) filozofię przyrody (jak również filozofię w ogóle) charakteryzuje wielość wspólistniejących ze sobą koncepcji, w ramach których różnie pojmuje się jej cel, przedmiot i metodę badań. Charakterystyczną cechą filozofii, odróżniającą ją od nauk przyrodniczych, jest również ciągle podejmowana refleksja nad własnymi podstawami” (Łukasik 2010, 7). Anna Latawiec, obok różnorodności metodologicznej, wskazuje kolejne dwie cechy współczesnej filozofii przyrody. Są nimi interdyscyplinarność oraz swoista dynamika rozwojowa filozofii przyrody (Latawiec 2010). Powrócę do nich w dalszej części artykułu. 
Obecnie chciałbym skupić się na różnorodności (względnie niejednorodności) metodologicznej i niektórych konsekwencjach tej cechy filozofii przyrody. Wydaje się bowiem, że różnorodność w sposobach rozumienia przedmiotu, zadań, celów i metod stosowanych w filozofii przyrody zagraża wewnętrznej integralności tej dyscypliny. W związku z tym pojawia się obawa, czy termin „filozofia przyrody” dziś jeszcze cokolwiek oznacza? Czy dyscyplina filozoficzna określana jako filozofia przyrody dziś wciąż istnieje? Czy można mówić nadal o tożsamości tej dyscypliny? Elementami składającymi się na tożsamość danej dyscypliny są jednolitość, integralność i autonomiczność tak określonego wycinka danej dziedziny wiedzy (Kamiński 1981). W przypadku filozofii przyrody chodzi o jej metodologiczną jedność (przejawiającą się również jako jednolitość, bądź też jako jednorodność), integralność i autonomiczność względem innych dyscyplin filozofii, ale i dziedzin wiedzy, np. nauki, a w szczególności względem nauk przyrodniczych.

Próba odpowiedzi na wyżej postawione pytania zostanie poprzedzona bliższym przyjrzeniem się trzem wymienionym wyżej cechom charakterystycznym współczesnej filozofii przyrody.

\section{NIEJEDNORODNOŚĆ METODOLOGICZNA FILOZOFII PRZYRODY}

Anna Latawiec swój artykuł $W$ poszukiwaniu obrazu wspótczesnej filozofi przyrody rozpoczyna od wyrażenia obawy ujawnionej w dyskusji w trakcie VII Polskiego Zjazdu Filozoficznego: „Czy w ogóle dyscyplina, jaką jest filozofia przyrody, jeszcze istnieje i jakie racje za jej istnieniem przemawiają? Obawy te pojawiają się już z chwilą wskazania przyjmowanej koncepcji tej dyscypliny" (Latawiec 2010, 29). Autorka obawę tę oddala w konkluzji swojego artykułu, twierdząc, że istnieje współczesna filozofia przyrody i że posiada ona właściwą sobie dynamikę rozwojową. Jednakże warunkiem koniecznym do przyjęcia tej konkluzji jest przyjęcie określonej koncepcji tej dyscypliny, określanej przez Annę Latawiec jako propozycja systemowego ujęcia 
filozofii przyrody. „Ujęcie takie wymagałoby określenia [filozofii przyrody -J.J.] jako systemu całościowego, względnie stabilnego, samoorganizującego się, podatnego na obieg informacji w jego wnętrzu i wymiany jej z otoczeniem" (Latawiec 2010, 39). To zaś pozwoliłoby zachować jej wewnętrzną spójność, pomóc w zrozumieniu jej metodologicznej złożoności i niejednorodności, a także uwolnić filozofię przyrody „od konieczności traktowania tej dyscypliny jako "zbiornika na wszystko« (różne koncepcje, różne metody, różne przedmioty)" (Latawiec 2010, 40). A zatem z propozycji autorki wynika, że zachowanie tożsamości filozofii przyrody wymaga przynajmniej częściowej rezygnacji z metodologicznej różnorodności (niejednorodności). Dla niektórych autorów tego typu konstatacja może być wręcz nie do przyjęcia. „Nie ma jednej słusznej filozofii przyrody”, stwierdza Janusz Mączka (Mączka 2013, 64), a jednym z powodów konieczności utrzymania metodologicznej różnorodności tej dyscypliny są, w pierwszej kolejności, osobiste preferencje (filozoficzne) każdego filozofa (przyrody), których, chociażby na etapie określania przedmiotu tej dyscypliny filozofii, nie da się wyeliminować. Kolejny powód jest związany z coraz głębszym wyodrębnianiem się nowych dziedzin nauki. „W konsekwencji będą generowane coraz to nowe problemy do rozwiązania. Trudność będzie polegała na tym, aby nauczyć się dostrzegać i dobrze formułować zagadnienia filozoficzne. Rozwój nauki to ważny argument za tym, że filozofia przyrody nie może wskazać na jeden uniwersalny model jej uprawiania, a tym bardziej nie będzie mogła jasno określić, co zawarte byłoby pod pojęciem [jej-J.J.] przedmiotu" (Mączka 2013, 65).

Inną konsekwencją różnorodności metodologicznej filozofii przyrody jest trudność zakwalifikowania poglądów danego myśliciela jako przynależnych do tej dyscypliny. Trudności w przypisywaniu konkretnych poglądów do określonego nurtu, szkoły czy dyscypliny filozoficznej występują w całej filozofii. Dotychczas wysuwane przez niektórych postulaty, m.in. mówiące o tym, że ,jedność w wielości musi być uzupełniona przez sztukę widzenia różnorodności 
w tym, co z pewnego punktu widzenia jest identyczne" (Miś 2003, 8), w stosunku do współczesnej filozofii przyrody należałoby raczej odwrócić. Dziś różnorodność (niejednorodność) metodologiczna filozofii przyrody wydaje się utrudniać (albo wręcz uniemożliwiać) zidentyfikowanie danych twierdzeń jako przynależnych do obszaru badawczego tej dyscypliny. Przykładem może być wypowiedź Michała Hellera, który ową trudność wyraża następująco: „Pisząc (...) rzadko zastanawiam się nad tym, czy poruszany temat należy do dziedziny fizyki, filozofii przyrody, kosmologii »przyrodniczej« czy »filozoficznej« (...). Po prostu interesuje mnie temat i staram się z nim zmierzyć. A że interesują mnie zagadnienia $\mathrm{z}$ różnych obszarów, często z pogranicza, trudno je potem sklasyfikować" (Heller 2005, 408). Nie chodzi o to, aby sztywno trzymać się jednej dyscypliny, nie wychodzić poza jej granice i tym samym zamykać się w swoistej „dyscyplinarnej bańce”4. Chodzi natomiast o zachowanie świadomości metodologicznej i unikanie błędów związanych z mieszaniem płaszczyzn poznawczych odrębnych metodologicznie i przedmiotowo dziedzin wiedzy, zwłaszcza w zakresie wysuwania wniosków i proponowania rozwiązań problemów w jednej płaszczyźnie na podstawie wyników osiągniętych w innej. Cytowany wyżej Michał Heller tego typu świadomość metodologiczną zachowuje: „Ale gdy porusza się takie zagadnienia, trzeba uważać na metodologię bardziej niż w innych przypadkach. No i jednak rodzi się pytanie: czy to jeszcze jest fizyka, czy już może filozofia przyrody? Nawet jeżeli sam sobie tego pytania nie stawiam, postawi je wkrótce jakiś dyskutant" (Heller 2005, 409). Poza tym współcześnie odchodzi się już od skrajnie rozumianej monodyscyplinarności. „Nie ma radykalnie

4 Dziękuję w tym miejscu prof. Krzysztofowi Kiljanowi za zwrócenie uwagi na ten problem w dyskusji nad referatem Dynamiczna koncepcja filozofii przyrody, stanowiącym punkt wyjścia niniejszego artykułu, który został wygłoszony przeze mnie w trakcie XIV Warsztatów Filozofii Przyrody organizowanych przez Sekcję Filozofii Przyrody i Nauk Przyrodniczych Polskiego Towarzystwa Filozoficznego (Kazimierz Dolny, 1-4.07.2021). 
monodyscyplinarnych obszarów badawczych. Co więcej, jeśli jakaś dyscyplina jest pozbawiona jakichkolwiek związków (przedmiotowych i konceptualnych) z innymi dyscyplinami, to nie jest częścią całościowego systemu wiedzy (nie jest nauką). W ramach systemu wiedzy jest miejsce co najwyżej na względnie izolowane podsystemy teoretyczne oraz względnie autonomiczne obszary badań. W konsekwencji tendencje izolacjonistyczne należy traktować jako charakterystyczne dla postawy sekciarskiej, a nie podejścia naukowego" (Bunge 2003, 281 - cyt. za: Poczobut 2012, 56). Natomiast „całościowy system wiedzy przypomina rozetę składającą się z setek częściowo zachodzących na siebie elips reprezentujących poszczególne dyscypliny nauki. W tym obrazie obszary przecięcia (części wspólne) symbolizują interdyscypliny i interdyscyplinarne programy badawcze" (Poczobut 2012, 55) 5 .

Trudności w zakwalifikowaniu poglądów danego myśliciela jako przynależnych do pola badawczego filozofii przyrody lub jego samego jako zajmującego się filozofią przyrody można ukazać na przykładzie rozważań prowadzonych przez Martynę Wielewską-Bakę w monografii Projekt interdyskursu. O tekstowym przekraczaniu granic między naukami w twórczości Michata Hellera (Wielewska-Baka 2020). Autorka przywołuje różnorakie role, w jakich Heller występuje: filozofa, filozofa nauki, naukowca (kosmologa), księdza, duszpasterza czy wreszcie popularyzatora nauki, która to rola wydaje się być szczególnie ważna dla badanego przez nią zagadnienia, a mianowicie przynależności pisarstwa Hellera do projektu „interdyskursu”6 i związanego

5 Problemem interdyscyplinarności w filozofii przyrody zajmę się w dalszej części artykułu i odniosę się do przywołanych w tym miejscu twierdzeń.

6 „[Intedyskursywność - J.J.] jest sferą działania filologa, który skupia uwagę na tekście; pytanie o interdyskurs to pytanie o to, w jaki sposób realizowana jest interdyscyplinarność w tekście; (...) interdyskursywność to przekraczanie granic tekstu: jego właściwości gatunkowych, stylistycznych, komunikacyjnych" (Wielewska-Baka 2020, 24). Zaś tytułowe „pojęcie projektu interdyskursywnego jest bardziej ogólne [od projektu interdyscyplinarnego - J.J.] i pozwala zwrócić uwagę na fundamentalny (również dla 
z tym pojęciem tytułowego tekstowego przekraczania granic między naukami ${ }^{7}$. W tych rozważaniach filozofia przyrody ma znaczenie co najwyżej marginalne. Sam termin „filozofia przyrody” pojawia się kilkukrotnie, m.in. we fragmencie poświęconym możliwości połączenia dyskursów prowadzonych w filozofii i naukach przyrodniczych, a także w prezentacji czasopism filozoficznych, w których Heller publikuje (Wielewska-Baka 2020). Autorka wydaje się nie postrzegać Michała Hellera jako filozofa przyrody, choć postrzega go już np. jako filozofa nauki. W związku z tym pojawia się pytanie: z czego to wynika? Czy z tego, że wspólczesna filozofia przyrody jest bardzo „niszową” dyscypliną filozofii (Latawiec 2006), którą już prawie nikt - poza garstką filozofów w Polsce - się nie zajmuje? ${ }^{8} \mathrm{Czy}$ też może „winne” jest tutaj wspomniane już rozmycie tożsamości filozofii przyrody, którego powodem jest - paradoksalnie - jedna $\mathrm{z}$ jej cech charakterystycznych?

Różnorodność metodologiczna filozofii przyrody wydaje się wynikać nie tylko z osobistych preferencji przedstawicieli tej dyscypliny (Mączka 2013), ale również z ujawniającej się na wyższym poziomie

Hellera) problem niemożliwości porozumienia dyskursu humanistycznego i dyskursu nauk ścisłych" (Wielewska-Baka 2020, 24).

7 „Hellerowski esej jest niemal zawsze rozpięty pomiędzy współrzędnymi interdyskursywnego układu triadycznego: pomiędzy nauką (science), teologią (religią) i filozofią" (Wielewska-Baka 2020, 129).

8 Przykładem lokalności filozofii przyrody może być chociażby przypadek czasopisma Philosophia Naturalis, o którym Zygmunt Hajduk pisał: „Ukazujące się od roku 1950 czasopismo o zasięgu międzynarodowym Philosophia Naturalis publikuje materiały o takim profilu problemowym [chodzi o filozofię przyrody - J.J.] (Hajduk 2004, 29). Analogiczną informację można odnaleźć w haśle Filozofia przyrody (Hajduk 2016) znajdującym się w Encyklopedii filozofii przyrody (2016). Natomiast na stronie wydawcy tegoż czasopisma można odnaleźć informację, że po 2013 roku zaprzestano jego wydawania (https://www. klostermann.de/epages/63574303.sf/de_DE/?ObjectPath=/Shops/63574303/Categories/ Zeitschriften/Phil-nat), [dostęp 2021/07/15]. Podobnie też czasopismo Philosophy in Science, do którego odwoływała się w swojej pracy również Martyna Wielewska-Baka (Wielewska-Baka 2020), i które stanowiło „bliźniacze” czasopismo względem Zagadnień Filozoficznych w Nauce, wydawane było tylko do roku 2003 (Polak 2019). 
uporządkowania dziedzin wiedzy niejednorodności relacji pomiędzy filozofią a nauką. Stanisław Kamiński w swojej monografii poświęconej Pojęciu nauki i klasyfikacji nauk stwierdza, że „filozoficzna wiedza nie stanowi jedynie pewnego przejściowego stadium rozwojowego nauk, czy to przednaukowego, czy ponaukowego, ale odrębny rodzaj poznania zarówno ze względu na swój przedmiot, jak i zadania, które stawia jej życie. W konsekwencji posiada też odrębną metodę" (Kamiński 1981, 280). Jednocześnie zaś mówi on, że bardzo trudno jest wyznaczyć granicę pomiędzy filozofią a naukami szczególowymi. „Często bowiem problematyka filozofii autonomicznej bywa podbudowana analizą i refleksją nad faktami lub teoriami naukowymi. Natomiast poznanie naukowe, bardziej teoretyczne, zostaje obudowane co najmniej uwagami, jeśli nie rozważaniami typu filozoficznego" (Kamiński 1981, 282). Można więc traktować filozofię albo jako jedną z nauk szczegółowych, albo jako swoistą metanaukę. Taka zaś metafilozoficzna różnorodność filozofii przekłada się na metodologiczną różnorodność filozofii przyrody. Na przykład niektórzy autorzy traktują filozofię przyrody jako nieautonomiczną dyscyplinę filozofii (z kolei jako autonomiczną dyscyplinę traktuje filozofię przyrody np. A. Lemańska - Lemańska 1998), jako subdyscyplinę metafizyki (Melsen 1963; Kamiński 1981) czy ontologii (Krajewski 2005; Ogurcow 2011). Dla innych zaś filozofia przyrody przejmuje rolę całej dziedziny filozofii i wskazywana jest jako główny (właściwy) partner w dialogu z nauką (Piątek 2005; Krajewski 2011). Można jeszcze, dla porządku, wskazać stanowiska, w ramach których filozofia przyrody staje się nieodróżnialna od filozofii przyrodoznawstwa czy filozofii nauk przyrodniczych (Korpikiewicz 2006; Szydłowski 2006).

Kolejnego dowodu na paralelność pomiędzy metafilozoficzną różnorodnością filozofii i metodologiczną różnorodnością filozofii przyrody dostarcza jeden z zaproponowanych przez Stanisława Kamińskiego podziałów filozofii, mający na celu ukazanie zasadniczych jej typów. Głównym kryterium owego podziału jest „stosunek do nauk szczegółowych” (Kamiński 1981, 282). Wyróżnia on 
typy filozofii będące metodologicznie bądź to niezależne od nauki, bądź też z nią korespondujące (czyli według tego autora pozostające zasadniczo nieautonomiczne względem nauki) ${ }^{9}$. Odpowiada to stosowanym w rozważaniach nad statusem metodologicznym filozofii przyrody typologiom, przy czym tu relacja zachodzi pomiędzy filozofią przyrody a naukami przyrodniczymi. Jedną z takich typologii stanowi propozycja Zygmunta Hajduka, w której wyróżnia się trzy typy filozofii przyrody ze względu na źródło wiedzy o przyrodzie oraz ze względu na sposób uzasadniania stawianych w filozofii przyrody tez. „W filozofii przyrody pierwszego rzędu $\left(\mathrm{FP}_{1}\right)$ źródło to jest niezależne od konstrukcji budowanych w naukach przyrodniczych, w uzasadnianiu jej tez nie odwołujemy się zaś do wyników tych nauk. Takie uzasadnianie nazywa się bezpośrednim. Filozofia przyrody drugiego rzędu $\left(\mathrm{FP}_{2}\right)$ jest oparta na aktualnych teoriach przyrodniczych genetycznie i metodologicznie, a więc uzasadniająco. Takie uzasadnianie tez nazywa się pośrednim. W filozofii przyrody typu mieszanego (FPM) występują obydwa rodzaje świadectw. Obok wyników nauk przyrodniczych w uzasadnianiu uczestniczą explicite tezy określonego systemu filozoficznego, jego ontologii, epistemologii. Przy konstruowaniu w miarę adekwatnego obrazu świata korzysta się $\mathrm{z}$ określonych teorii naukowych oraz filozoficznych punktów widzenia" (Hajduk 2004, 178).

Podsumowując dotychczasowe rozważania, należy stwierdzić, że mamy do czynienia ze swoistym paradoksem. $Z$ jednej strony nie da się usunąć metodologicznej różnorodności (niejednorodności)

9 Do filozofii autonomicznych metodologicznie względem nauki S. Kamiński zalicza po pierwsze: filozofie, które dopuszczają również pozaracjonalne źródła poznania czy też „pozateoretyczne” kryteria rozstrzygalności, po drugie: filozofie spekulatywne (aprioryczne, konstrukcyjne) i po trzecie: filozofie klasyczne (aposterioryczne). Natomiast do filozofii nieautonomicznych względem nauki zalicza po pierwsze: filozofie będące dopełnieniem nauki - będące poznaniem przednaukowym lub tworzącym bądź podstawy owych nauk, bądź całość systemu wiedzy racjonalnej lub nadbudowanym na poznaniu naukowym, a po drugie: filozofie będące metanaukami - w tym przypadku będące znów albo analizą krytyczną wiedzy lub jej podstawowych pojęć, albo logiką wiedzy (Kamiński 1981). 
z filozofii przyrody, gdyż stanowi ona jej cechę charakterystyczną, czyli budującą tożsamość filozofii przyrody jako dyscypliny filozoficznej. $Z$ drugiej strony ta właśnie jej cecha wpływa na rozmywanie się owej tożsamości. W związku z powyższym można postawić pytanie, czy da się, (a jeśli tak, to w jaki sposób), zachować tożsamość filozofii przyrody bez rezygnacji z jej metodologicznej różnorodności? Pozytywnej odpowiedzi na powyższe pytanie dostarczają analizy pojęcia jedności nauki prowadzone przez Stanisława Kamińskiego (Kamiński 1981). Oprócz metodologicznej jednorodności ${ }^{10}$ lub jednolitości ${ }^{11}$ dyscyplin naukowych istnieje też trzecia postać, w jakiej realizować może się jedność danej dziedziny. „Pośrednim typem jedności nauki jest integracja, która przeważnie powstaje w wyniku przenikania się nauk dzięki dyscyplinom pogranicznym" (Kamiński 1981, 250). A zatem jedność i tym samym tożsamość filozofii przyrody, przy zachowaniu jej metodologicznej różnorodności, można zachować dzięki interdyscyplinarności, która stanowi drugą z trzech cech charakterystycznych tej dyscypliny filozofii.

\section{INTERDYSCYPLINARNOŚĆ FILOZOFII PRZYRODY}

Anna Latawiec rozumie interdyscyplinarność jako zdolność filozofa przyrody, również w aspekcie przygotowania merytorycznego, do prowadzenia dociekań filozoficznych obejmujących kilka dyscyplin naukowych jednocześnie, nie tylko w dziedzinie filozofii, ale również (a może głównie) w dziedzinie nauk szczegółowych,

10 Jednorodność dyscyplin naukowych polega na tym, że „wszystkie dyscypliny spełniają te same kryteria naukowości, zwłaszcza co do typu języka i metody, oraz możliwy jest choćby częściowy redukcjonizm. Nauka to jakby jeden las złożony z wielu drzew albo płot zrobiony z jednakowych sztachet” (Kamiński 1981, 250).

11 W przypadku jednolitości dyscyplin naukowych chodzi o „scalenie nauk i ich zawartości, aby można było otrzymać spójny układ wiedzy (wspólne pryncypia i zadania oraz częściowo zintegrowana treść). (...) nauka to jakby jeden organizm (np. drzewo) albo przynajmniej mozaika, która wprawdzie składa się z wielu kamyków-dyscyplin, ale tworzy jeden obraz" (Kamiński 1981, 250-251). 
w szczególności w obszarze nauk przyrodniczych. Wspomniana zdolność powinna również obejmować umiejętność „zespołowej pracy nad rozwiązywaniem konkretnego problemu" (Latawiec 2010,37) lub problemów, mających charakter interdyscyplinarny (np. problem początku wszechświata, zagadnienie początku życia, kwestie związane z czasem i przestrzenią oraz wiele innych, stanowiących tradycyjnie problemy podejmowane $\mathrm{w}$ ramach filozofii przyrody). Powyższe rozumienie interdyscyplinarności na terenie filozofii przyrody jest przykładem tylko jednego z typów interdyscyplinarności, który Julie Klein określa jako multidyscyplinarność. Oprócz tego, wyróżnia się dwa inne główne jej rodzaje ${ }^{12}$ : interdyscyplinarność (w węższym znaczeniu) i transdyscyplinarność (Klein 2010; 201713; Poczobut 2012).

Z kolei o interdyscyplinarności w węższym tego słowa znaczeniu można mówić wtedy, gdy pojawiają się problemy na styku dwóch różnych dyscyplin lub teorii naukowych, bądź też takie, które wymagają interakcji pomiędzy dwoma różnymi poziomami organizacji materii, chodzi o tzw. zależności międzypoziomowe. Kluczowe dla tak rozumianej interdyscyplinarności jest istnienie niepustego zbioru zawierającego formuły łączące dwie dyscypliny bazowe. W tych formułach powinny występować terminy (pojęcia) specyficzne dla obydwu tych dyscyplin. Jednocześnie musi być spełniony warunek istnienia niepustej części wspólnej pomiędzy dziedzinami ich dyskursu

12 W ramach każdego z wyróżnionych rodzajów interdyscyplinarności dokonuje się kolejnych dystynkcji, zwiększających liczbę typów interdyscyplinarności. Ostatecznie więc interdyscyplinarność jest pojęciem niezwykle wieloznacznym. W związku z tym, prowadząc rozważania na jej temat, należy pamiętać, z jakim rozumieniem interdyscyplinarności mamy w danym momencie do czynienia.

13 Artykuł Klein z roku 2017, opublikowany w drugim wydaniu The Oxford Handbook of Interdisciplinarity, jest poprawioną wersją jej artykułu z roku 2010, który został opublikowany w pierwszym wydaniu tego podręcznika. W drugim wydaniu The Oxford Handbook of Interdisciplinarity połowa artykułów została zmodyfikowana, a druga zastąpiona zupełnie nowymi, co wynikało ze zmian, jakie w okresie siedmiu lat zaszły w zakresie rozumienia, zasięgu geograficznego i instytucjonalnego zaangażowania w realizację idei interdyscyplinarności (Frodeman, Klein, Pacheco 2017). 
(Poczobut 2012). Tak rozumiana interdyscyplinarność pojawia się w poglądach Władysława Krajewskiego (Krajewski 2005), kiedy omawia on relacje pomiędzy filozofią przyrody a filozofią nauki. Według niego istnieje obszar pogranicza pomiędzy obiema dyscyplinami, w którym występują specyficzne problemy. W celu ich rozwiązania należy połączyć aspekty charakterystyczne dla każdej z dyscyplin (dla filozofii przyrody będzie to aspekt ontologiczny, a dla filozofii nauki - epistemologiczny). Jedno z tego typu zagadnień obejmuje problemy dotyczące tzw. realizmu naukowego w odniesieniu zarówno do obiektów postulowanych przez teorie nauk przyrodniczych, jak i w stosunku do prawdziwości teorii dobrze potwierdzonych przez doświadczenie. Drugie natomiast skupia się na problemach dotyczących istoty zjawisk i procesów odkrywanych lub konstruowanych (jako idealne modele zjawisk) przez teorie nauk przyrodniczych. Poszukuje się tu ,istoty rzeczywistych procesów, a zarazem tego, jak do nich dotrzeć za pomocą nauki, wychodząc od obserwowanych zjawisk" (Krajewski 2005, 421).

Wydaje się, że pomiędzy multidyscyplinarnością a interdyscyplinarnością w węższym znaczeniu można jeszcze wyróżnić obszar pośredni (w którym mamy do czynienia z czymś więcej niż multidyscyplinarność, ale nie jest to jeszcze interdyscyplinarność, o której była mowa), w którym można umieścić dialog pomiędzy tradycyjnie odrębnymi dyscyplinami czy dziedzinami wiedzy. Filozofia przyrody również może pełnić tego typu funkcję. Zwrócił na to uwagę Zygmunt Hajduk (Hajduk 2013), a jako przykład wskazał pracę Adama Świeżyńskiego (Świeżyński 2012), w której odnajdujemy filozofię przyrody jako płaszczyznę dialogu pomiędzy wynikami nauk przyrodniczych a niektórymi tezami teologii. Inne przejawy tak rozumianej interdyscyplinarności filozofii przyrody można odnaleźć np. w poglądach Zdzisławy Piątek (Piątek 2005) czy Jana Czerniawskiego (Czerniawski 2006).

Trzecim rodzajem interdyscyplinarności jest transdyscyplinarność. „Transdyscyplinarność wchodzi na scenę wówczas, gdy wykorzystując 
różne poziomy reprezentacji rzeczywistości, a także wszelką wiedzę dostępną w ramach badań mono- i interdyscyplinarnych, konstruujemy teorie na jeszcze wyższym poziomie abstrakcji” (Poczobut 2012, 58). Prowadzenie badań transdyscyplinarnych dostarcza abstrakcyjnych pojęć, modeli, czy też kategorii, które następnie znajdują zastosowanie w dyskursach bardziej szczegółowych dyscyplin. Tak rozumiana interdyscyplinarność będzie również występować w filozofii przyrody wszędzie tam, gdzie prowadzone rozważania zmierzają do wypracowania ogólnej wizji przyrody (Korpikiewicz 2006; Szczuciński 2006) czy w holistycznej ontologii świata materialnego (Nowak 2006), ale również tam, gdzie mamy do czynienia ze swoistą transmutacją struktur pojęciowych pomiędzy naukami szczegółowymi a filozofią (Heller 2008).

Powiązanie interdyscyplinarności z jednością wiedzy (Klein 1990; Bunge 2003; Kurczewska 2014), z którym wiąże się z kolei nadzieja na odnalezienie zagubionej tożsamości filozofii przyrody, budzi kontrowersje. Szymon Wróbel (Wróbel 2014) ubrał w formę paradoksu konsekwencje przywoływanych wyżej twierdzeń Mario Bunge (Bunge 2003) na temat całokształtu wiedzy ludzkiej i braku w nim odizolowanych względem siebie dziedzin wiedzy. Paradoks ów wyraża się w następującej alternatywie: „albo jedność nauki jest nie do utrzymania, ale wówczas, nie do utrzymania jest też idea interdyscyplinarności, albowiem współpraca między dyscyplinami posługującymi się różnymi niesprowadzalnymi do siebie metodologiami (językami opisu) jest niemożliwa, a może nawet szkodliwa, albo też jedność nauki da się dowieść, ale wtedy problem interdyscyplinarności staje się problemem pozornym, albowiem pozorna jest autonomia poszczególnych dyscyplin naukowych” (Wróbel 2014, 15).

Z powyższego wynika, że interdyscyplinarność stanowi swoisty i prowadzący do paradoksów efekt dyscyplinarności wiedzy ludzkiej. W odniesieniu do filozofii przyrody można więc postawić pytanie, który z członów alternatywy zaproponowanej przez Szymona Wróbla wybrać. Jeżeli wybierzemy pierwszy człon, to interdyscyplinarność 
przestanie być jedną z form jedności nauki, a tym samym wracamy do punktu wyjścia w poszukiwaniach zagubionej tożsamości filozofii przyrody. Jeżeli zaś wybierzemy drugi człon alternatywy, wtedy będziemy musieli pójść drogą, o której wspominała Anna Latawiec (Latawiec 2006), czyli będziemy musieli ograniczyć (lub całkowicie zredukować) różnorodność metodologiczną filozofii przyrody. To zaś spowoduje również usunięcie (poprzez jej strywializowanie) interdyscyplinarności ze zbioru cech charakterystycznych dla współczesnej filozofii przyrody. To z kolei zdaje się burzyć całość dotychczas prowadzonych analiz, bazujących na przyjętym w punkcie wyjścia metafilozoficznym oglądzie tej dyscypliny. Czy istnieje zatem rozwiązanie paradoksu, przywołanego przez Szymona Wróbla, jedności nauki w połączeniu z interdyscyplinarnością? Odpowiedź, jakiej udziela sam Wróbel na to pytanie, jest pozytywna. Wymogi interdyscyplinarności mogłaby spełniać tzw. wiedza emancypacyjna. „Nie służy ona ani lepszemu panowaniu nad rzeczywistością, ani też lepszemu rozumieniu, ale służy zwiększeniu stopnia swobody działania podmiotu myślącego" (Wróbel 2014, 17). W związku z tym pojawia się pytanie, czy mamy z czymś takim do czynienia w filozofii przyrody? Wydaje się, że tak, a jako przykład mogą służyć zaprezentowane w trakcie debaty podczas VIII Polskiego Zjazdu Filozoficznego poglądy Mieczysława Lubańskiego (Lubański 2005b) i Teresy Grabińskiej (Grabińska 2006).

Mieczysław Lubański wykazuje, że filozofia przyrody czyni człowieka odpornym na subiektywne i jednostronne ujęcia rzeczywistości, jakie niesie ze sobą ponowoczesność. W szczególności chroni przed próbami manipulacji, w tym zastraszania lub wzbudzenia nienależnego uznania wśród osób niezaznajomionych w wystarczającym stopniu z wynikami nauk przyrodniczych, które to próby przyjmują postać narracji wykorzystujących terminologię i język nauk szczególowych. Filozofia przyrody, umożliwiając logiczno-metodologiczny wgląd w osiągnięcia tych nauk, ułatwia „dokonywanie właściwej oceny osiągnięć, zwłaszcza o charakterze techniczno-technologicznym, 
w odniesieniu do celu i sensu życia" (Lubański 2005b, 417). A zatem, filozofia przyrody, chroniąc człowieka przed skutkami manipulacji, zwiększa jego swobodę działania.

Z kolei w ujęciu Teresy Grabińskiej filozofia przyrody zwiększa swobodę komunikacji pomiędzy przedstawicielami różnych dyscyplin i dziedzin wiedzy. „Jedynym sposobem komunikacji [wolnym od zniekształceń i innych błędów - J.J.] między uprawiającymi wiedzę ezoteryczną ${ }^{14}$ a tymi, którzy pozostając na zewnątrz, chcą lub powinni (jak filozofowie) mieć w nią wgląd, jest przekaz tej wiedzy na poziomie filozofii przyrody, tzn. w filozoficznych kategoriach oglądu przyrodniczego lub/i na poziomie metafizyki szczegółowej, tzn. na poziomie odtwarzania obrazu świata w oparciu o aparaturę pojęciową, badanie warstwy znaczeniowej języka teorii, relacji $\mathrm{R}^{15}$ oraz pochodzenia i sensu konwencji i idealizacji” (Grabińska 2006, 334).

Podsumowując dotychczasowe rozważania na temat interdyscyplinarności w filozofii przyrody, można powiedzieć, że wynikające z niej wzmocnienie tożsamości filozofii przyrody wiąże się z dodatkowymi korzyściami, polegającymi na zwiększeniu swobody myślenia i działania, w tym zwiększeniu swobody komunikacji pomiędzy osobami zajmującymi się filozofią przyrody a ,jednostką, społeczeństwem, kulturą i nauką w »rozregulowanym świecie»" (Kurczewska 2014, 9).

\section{DYNAMIKA ROZWOJOWA FILOZOFII PRZYRODY}

Dopełnieniem charakterystyki metafilozoficznej współczesnej filozofii przyrody jest jej dynamika rozwojowa. Jednym z jej źródeł

14 Wiedza ezoteryczna pojawia się w ezoterycznym kręgu wiedzy, czyli jest wytwarzana przez (i przekazywana do) specjalistów, zajmujących się profesjonalnie daną dziedziną (Fleck 1986).

15 „Według realistów poznawczych relacja $\mathrm{R}$ jest to relacja, w jakiej pozostają teorie przyrodoznawstwa względem swoich przedmiotów. Relacja R umożliwia wzajemne przyporządkowanie elementów rzeczywistości zjawiskowej i elementów teoretycznych" (Grabińska 2006, 334). 
wydają się być (jawiące się jako skomplikowane i niejednoznaczne) relacje pomiędzy filozofią przyrody a naukami przyrodniczymi. "Jeżeli bowiem prawdą jest, że w ramach filozofii przyrody wykorzystuje się dane naukowe zaczerpnięte $z$ nauk przyrodniczych, to każdy nowy fakt naukowy, każde nowe odkrycie, każda nowa teoria czy hipoteza mobilizują do podjęcia na nowo refleksji filozoficznej, odkrywania nowych faktów filozoficznych" (Latawiec 2010, 38). Jednocześnie Anna Lemańska postuluje, aby korzystanie z danych pochodzących $\mathrm{z}$ nauk przyrodniczych w filozofii przyrody odbywało się przy wzajemnej akceptacji autonomiczności każdej z dyscyplin. Szkodliwe wydaje się zarówno stawianie jako nadrzędnych bądź to nauk przyrodniczych, bądź też filozofii przyrody, jak i traktowanie obydwu tych dziedzin jako zupełnie izolowanych względem siebie (Lemańska 2013). Filozof przyrody powinien zachować równowagę. $\mathrm{Z}$ jednej strony nie może on odcinać się od wyników nauk przyrodniczych, gdyż uprawianie filozofii przyrody w oparciu o przestarzała wiedzę lub tylko o poznanie potoczne czy poznanie intuicyjne prowadzić będzie do twierdzeń, które nie przystają do świata materialnego. $Z$ drugiej zaś strony zbyt silne związanie z perspektywą nauk przyrodniczych może spowodować utratę specyficznej dla filozofii perspektywy badawczej, przemieniając filozofię przyrody w filozofię przyrodoznawstwa czy ontologię teorii przyrodniczej (Lemańska 2010). Właściwym zaś rozwiązaniem wydaje się swoiste balansowanie pomiędzy przedstawionymi wyżej skrajnościami. „Chodzi o to, by filozof przyrody zaczynał od stawiania pytań filozoficznych, a nie od zgłębiania szczegółowej wiedzy z zakresu nauk przyrodniczych" (Lemańska 2010, 48). Oczywiście informacje o rzeczywistości mogą pochodzić zarówno z poznania potocznego, jak i z poznania naukowego. Jeżeli źródłem pewnych faktów o przyrodzie są nauki przyrodnicze, np. jakaś teoria naukowa, to konieczne staje się również opracowanie owych faktów za pomocą narzędzi dostarczanych przez filozofię przyrodoznawstwa (stanowiącą część filozofii nauki). Zastosowanie tych narzędzi umożliwi, chociażby przybliżoną, ocenę owych faktów 
pod kątem ich adekwatności, tzn. pozwoli na odróżnienie twierdzeń ugruntowanych w danej nauce od pojawiających się w niej hipotez. Następnie wyniki owych analiz filozof przyrody powinien odnieść bezpośrednio do przyrody, czyli do świata materialnego lub jego określonego fragmentu. W ten sposób możliwe jest sprawdzanie w oparciu o wiedzę o świecie materialnym pochodzącą zarówno $\mathrm{z}$ poznania potocznego, jak i z nauk przyrodniczych stawianych przez filozofa przyrody filozoficznych hipotez dotyczących świata materialnego, jego istotnych właściwości, natury, itd. (Lemańska 1998).

Warto od razu w tym miejscu zaznaczyć, że w odniesieniu do problemu tożsamości filozofii przyrody opisana wyżej jej dynamika, opierająca się na relacji (przyjmującej rozmaite postacie, co wynika z różnorodności metodologicznej filozofii przyrody), jaka zachodzi pomiędzy filozofią przyrody a danymi pochodzącymi z nauk przyrodniczych, stanowi cechę wyróżniającą filozofię przyrody wśród innych dyscyplin filozoficznych. Można jednak również spróbować zastanowić się nad pytaniem, czy ta cecha może być odzwierciedleniem (podobnie jak było to w przypadku cechy różnorodności metodologicznej) metafilozoficznych właściwości samej filozofii. Czy charakterystyczne dla filozofii przyrody swoiste „balansowanie” pomiędzy odrębnymi (i pozornie wykluczającymi się) perspektywami dokonuje się również na terenie filozofii?

Odpowiedź twierdzącą na postawione wyżej pytanie można znaleźć w zaproponowanym przez Jacka Wojtysiaka (Wojtysiak 2015) sposobie uprawiania filozofii. Na początku dokonuje on pewnego metafilozoficznego podziału. Wyróżnia filozofię czystą i stosowaną. Ta pierwsza jest rdzeniem filozofii z historycznego i merytorycznego punktu widzenia. Jej uprawianie służy tylko i wyłącznie wewnętrznym celom filozofii, czyli dąży się w niej do poznania i zrozumienia rzeczywistości. „Jej zadaniem jest rozpatrywanie zagadnień specyficznie filozoficznych bez względu na ich powiązania $z$ tematyką niefilozoficzną oraz na pozafilozoficzne funkcje lub konsekwencje tej czynności” (Wojtysiak 2015, 21-22). Z kolei filozofia stosowana 
uprawiana jest przede wszystkim na użytek innych dziedzin wiedzy. W kolejnym kroku filozofia czysta zostaje podzielona na filozofię światopoglądową ${ }^{16}$ i filozofię techniczną ${ }^{17}$, zaś filozofia stosowana na filozofię humanistyczną ${ }^{18}$ i filozofię naukową ${ }^{19}$.

W związku z tym podziałem pojawia się pytanie, w jaki sposób filozof ma prowadzić swoje rozważania? „Czy rzetelny filozof skazany jest na nieustanne wewnętrzne napięcie między cnotą mądrości a cnotą intelektualnej transcendencji, między pragnieniem trwałego uchwycenia podstaw całości a radykalnym krytycyzmem, między kontemplatywną wizją a intelektualną grą, między pewnością zwrotu »tak jest« a dywagacjami wyrażanymi przez zwrot »a może jest inaczej«?” (Wojtysiak 2015, 29). W odpowiedzi autor wskazuje, że swoiste balansowanie pomiędzy przedstawionymi opcjami metafilozoficznymi „stanowi nieusuwalny rys kondycji prawdziwego filozofa" (Wojtysiak 2015, 29). Co więcej, nie oznacza to wcale, że filozof ma nie dążyć do osiągnięcia ideału, dzięki któremu uda mu się pogodzić ze sobą tendencję światopoglądową i techniczną. „Można bowiem (...) wyrażać i uzasadniać swój światopogląd w sposób na tyle krytyczny, na ile jest to możliwe. Można też radykalnie krytycznie rozpatrywać »małe zagadki« filozoficzne, by coraz bardziej

16 Filozofia światopoglądowa wyraża się „w pytaniach, za którymi kryje się intencja naszkicowania całościowego i (lub) najbardziej fundamentalnego obrazu rzeczywistości" (Wojtysiak 2015, 22).

17 Filozofia techniczna „zajmuje się pedantyczną analizą (niekoniecznie światopoglądowo nieważnych) zagadnień, które nie mieszczą się bezpośrednio w ramach nauk lub innych aktywności umysłowych. (...) [walorem jej jest - J.J.] intelektualna sprawność w prowadzeniu (...) »intelektualnej gry« lub rozwiązywaniu »małych zagadek«" (Wojtysiak 2015, 23).

18 W filozofii humanistycznej „wiodą prym historycy filozofii oraz filozofowie kultury i jej poszczególnych działów. (...) ich zadaniem jest pielęgnacja (zachowywanie i opracowywanie) pewnego fragmentu lub aspektu ludzkiej kultury, jest ona bowiem przeniknięta kwestiami czysto filozoficznymi” (Wojtysiak 2015, 21).

19 „[Filozofowie - J.J.] naukowi pomagają badaczom lub adeptom poszczególnych nauk w (re) konstruowaniu metod postępowania naukotwórczego, w tworzeniu syntez naukowych lub w identyfikacji podstaw (określonych obszarów) wiedzy" (Wojtysiak 2015, 21). 
przybliżać się do fundamentalnych prawd o rzeczywistości" (Wojtysiak 2015, 29).

W świetle powyższych stwierdzeń porównanie tak scharakteryzowanej dynamiki filozofii z dynamiką filozofii przyrody wydaje się być zasadne. Aby wzmocnić jeszcze ten wniosek, należy zauważyć, że choć przedstawiony tu podział dotyczy całej dziedziny filozofii, to można go również zastosować do poszczególnych jej dyscyplin, w szczególności do filozofii przyrody. W takim przypadku wśród rozmaitych koncepcji filozofii przyrody można odnaleźć takie, które w efekcie ich przyjęcia uczynią z filozofii przyrody filozofię czystą, zarówno w jej wersji światopoglądowej, jak i technicznej, czy też filozofię stosowaną, zarówno w jej wersji humanistycznej, jak i naukowej. Okazuje się więc, że dynamika rozwojowa jako metafilozoficzna cecha filozofii przyrody jest ugruntowana zarówno w perspektywie innych cech tej dyscypliny, czyli w perspektywie różnorodności metodologicznej oraz relacji pomiędzy filozofią przyrody a naukami przyrodniczymi, ujawniającej się przy okazji korzystania $\mathrm{w}$ tej dyscyplinie $\mathrm{z}$ danych pochodzących $\mathrm{z}$ nauk przyrodniczych (co stanowi pewną formę interdyscyplinarności filozofii przyrody), jak i na gruncie metafilozoficznego pejzażu całej dziedziny filozofii.

\section{ZAKOŃCZENIE}

Okazuje się, że należy (przynajmniej od czasu do czasu) podejmować problematykę związaną z metodologicznym statusem filozofii przyrody. Zachodzące dość szybko zmiany we współczesnej kulturze intelektualnej, których rysem charakterystycznym jest zwiększenie specjalizacji i rozdrobnienie pól badawczych poszczególnych dziedzin i dyscyplin wiedzy, przy jednoczesnej niechęci do poszukiwań ujęć jednoczących (integrujących) wiedzę, miały wpływ zarówno na filozofię, jak i w szczególności na filozofię przyrody. Stąd też ujawniona w metafilozoficznej charakterystyce współczesnej filozofii przyrody jej cecha różnorodności metodologicznej wydaje się być dziś czymś, 
z czego nie należy i nie warto rezygnować. Pozostałe dwie cechy, czyli interdyscyplinarność oraz dynamika rozwojowa filozofii przyrody, są silnie i wielorako powiązane z cechą różnorodności metodologicznej. Jednocześnie wszystkie trzy cechy są odzwierciedleniem bardziej ogólnych (metafilozoficznych) właściwości całej dziedziny filozofii, która również jest różnorodna pod względem metodologicznym (metafilozoficznym) i stanowi - w zasadzie - pierwowzór dla podejścia interdyscyplinarnego. Ponadto „zmusza” każdego rzetelnego filozofa do zachowywania dynamicznego napięcia pomiędzy różnymi typami dyskursu filozoficznego (od filozofii uprawianej dla niej samej, do świadczenia usług na rzecz przedstawicieli innych dziedzin, czy też od drobiazgowego rozpatrywania szczegółowych kwestii do prób odpowiedzi na wielkie pytania o dużym znaczeniu światopoglądowym) oraz do korzystania z wszelkich możliwych, ale maksymalnie krytycznie sprawdzonych, źródeł wiedzy o rzeczywistości. Skoro filozofia przyrody ma być częścią filozofii, to jej ujawnione cechy charakterystyczne sprzyjają budowaniu określonej tożsamości, która mieści się w zakresie (jest częścią) tożsamości całej dziedziny filozofii.

\section{BIBLIOGRAFIA}

(2005). Komu i po co potrzebna jest dziś filozofia przyrody? Punkty widzenia dyskutowane podczas VII Zjazdu Polskiego Towarzystwa Filozoficznego w Szczecinie, 17 września 2004 roku oraz wypowiedzi zebrane po Zjeździe (część 1). Roczniki Filozoficzne, 53(2), 405-437.

(2006). Komu i po co potrzebna jest dziś filozofia przyrody? Punkty widzenia dyskutowane podczas VII Zjazdu Polskiego Towarzystwa Filozoficznego w Szczecinie, 17 września 2004 roku oraz wypowiedzi zebrane po Zjeździe (część 2). Roczniki Filozoficzne, 54(1), 298-359.

Bremer, J., Leszczyński, D., Łucarz, S., Koszteyn, J. (2019). Piotr Lenartowicz. Kraków: Wydawnictwo Naukowe Akademii Ignatianum.

Bugajak, G. (2006). O luksusie filozofowania. Roczniki Filozoficzne, 54(1), 344-345.

Bugajak, G., Latawiec, A., Lemańska, A., Świeżyński, A. (2019). Kazimierz Kloskowski. Kraków: Wydawnictwo Naukowe Akademii Ignatianum. 
Bunge, M. (2003). Emergence and Convergence: Qualitative Novelty and the Unity of Knowledge. Toronto - Buffalo - London: University of Toronto Press.

Czerniawski, J. (2006). Filozofia przyrody jako sito. Roczniki Filozoficzne, 54(1), 299-302.

Fleck, L. (1986). Powstanie i rozwój faktu naukowego. Lublin: Wydawnictwo Lubelskie.

Frodeman, R., Klein, J.T., Pacheco, R.C.S. (2017). Preface. W: R. Frodeman, J.T. Klein, R.C.S. Pacheco (red.), The Oxford Handbook of Interdisciplinarity, 2nd edition, VII-VIII. Oxford-New York: Oxford University Press.

Grabińska, T. (2006). Filozofia przyrody a metafizyka szczegółowa. Roczniki Filozoficzne, 54(1), 329-334.

Grygiel, W.P. (2012). Między mikroświatem a makroświatem. Zagadnienia Filozoficzne w Nauce, 50, 46-62.

Grygiel, W.P. (2014). Stephena Hawkinga i Rogera Penrose’a spór o rzeczywistość. Kraków: Copernicus Center Press.

Grygiel, W.P. (2021). Jak scena stata się dramatem. Filozofia w kontekście teorii względności. Kraków: Copernicus Center Press.

Grzanka, J. (2020). Między fizykq a flozofia. Filozofia przyrody i filozofia fizyki w pismach Mariana Smoluchowskiego. Kraków: Wydawnictwo Universitas.

Hajduk, Z. (2004). Filozofia przyrody. Filozofia przyrodoznawstwa. Metakosmologia. Lublin: Towarzystwo Naukowe KUL.

Hajduk, Z. (2005). Komu i po co potrzebna jest dziś filozofia przyrody?. Roczniki Filozoficzne, 53(2), 412-415.

Hajduk, Z. (2006). Między filozofią przyrody a filozofią nauki. Zarys autobiogramu: studia, badania, dydaktyka, praca organizacyjna na Katolickim Uniwersytecie Lubelskim Jana Pawła II. Roczniki Filozoficzne, 54(2), 7-15.

Hajduk, Z. (2013). Koncepcje filozofii przyrody. W: S. Janeczek, A. Starościc, D. Dąbek, J. Herda (red.), Dydaktyka filozofii, t. 3: Filozofia przyrody, 15-29. Lublin: Wydawnictwo KUL.

Hajduk, Z. (2016). Filozofia przyrody. W: Z.E. Roskal (red.), Encyklopedia filozofi przyrody, 161-169. Lublin: Wydawnictwo KUL.

Heller, M. (2004). Filozofia przyrody. Zarys historyczny. Kraków: Wydawnictwo Znak.

Heller, M. (2005). Filozofia przyrody w działaniu. Roczniki Filozoficzne, 53(2), 408-410.

Heller, M. (2008). Nauki przyrodnicze a filozofia przyrody. W: M. Heller, Filozofia i wszechświat. Wybór pism, 26-33. Kraków: Universitas. 
Heller, M. (2011). Filozoficzny program Józefa Życińskiego. Zagadnienia Filozoficzne w Nauce, 48, 5-22.

Heller, M., i in. (red.). (2007a). Krakowska fllozofia przyrody w okresie międzywojennym. Tom 1. Początki. Tarnów: Biblos.

Heller, M., i in. (red.). (2007b). Krakowska filozofia przyrody w okresie międzywojennym. Tom 2. Matallmann, Zawirski, Gawecki. Tarnów: Biblos.

Heller, M., i in. (red.). (2007c). Krakowska filozofia przyrody w okresie międzywojennym. Tom 3. Smoluchorwski, Natanson, inni. Tarnów: Biblos.

Heller, M., Mączka, J. (2006). Początki filozofii przyrody w Ośrodku Badań Interdyscyplinarnych w Krakowie. Roczniki Filozoficzne, 54(2), 49-62.

Heller, M., Mączka, J. (2010). Joachima Metallmanna zarys koncepcji filozofii przyrody. Zagadnienia Filozoficzne w Nauce, 46, 141-161.

Heller, M., Mączka, J. (2011). Kilka uwag o uprawianiu historii kosmologii. Roczniki Filozoficzne, 59(2), 103-114.

Janeczek, S., Starościc, A., Dąbek, D., Herda, J. (red.). (2013). Dydaktyka filozofii, t. 3: Filozofia przyrody. Lublin: Wydawnictwo KUL.

Kamiński, S. (1981). Pojęcia nauki i klasyfikacja nauk. Lublin: Wydawnictwo TN KUL.

Klein, J.T. (1990). Interdisciplinarity: History, Theory, and Practice. Detroit: Wayne State University Press.

Klein, J.T. (2010). A Taxonomy of Interdisciplinarity. W: R. Frodeman, J.T. Klein, C. Mitcham (red.), The Oxford Handbook of Interdisciplinarity, 15-30. OxfordNew York: Oxford University Press.

Klein, J.T. (2017). Typologies of Interdisciplinarity: The Boundary Work of Definition. W: R. Frodeman, J.T. Klein, R.C.S. Pacheco (red.), The Oxford Handbook of Interdisciplinarity, 2nd edition, 21-34. Oxford-New York: Oxford University Press.

Korpikiewicz, H. (2006). Filozofia przyrody i jej znaczenie dla nauk przyrodniczych. Roczniki Filozoficzne, 54(1), 345-348.

Krajewski, W. (2005). Filozofia przyrody jako pomost między naukami przyrodniczymi a filozofią. Roczniki Filozoficzne, 53(2), 418-421.

Krajewski, W. (2011). Naukowa filozofia przyrody. W: W. Eugowski, I.K. Lisiejew (red.), Filozofia przyrody - dzis, 28-32. Warszawa: IFiS PAN.

Kurczewska, J. (2014). Wprowadzenie. W: J. Kurczewska, M. Lejzerowicz (red.), Gtosy w sprawie interdyscyplinarności. Socjologowie, flozofowie i inni o pojęciach, podejściach i swych doświadczeniach, 7-9. Warszawa: IFiS PAN.

Kuszyk-Bytniewska, M., Eukasik, A. (red.). (2010). Filozofia przyrody wspótcześnie. Kraków: Wydawnictwo Universitas. 
Latawiec, A. (2006). Próba obrony filozofii przyrody. Roczniki Filozoficzne, 54(1), 319-322.

Latawiec, A. (2010). W poszukiwaniu obrazu wspótczesnej filozofii przyrody. W: M. Kuszyk-Bytniewska, A. Łukasik (red.), Filozofia przyrody wspótcześnie, 29-41. Kraków: Wydawnictwo Universitas.

Lemańska, A. (1998). Filozofia przyrody a nauki przyrodnicze. Warszawa: Wydawnictwo ATK.

Lemańska, A. (2006). Cele i zadania filozofii przyrody. Roczniki Filozoficzne, 54(1), 322-325.

Lemańska, A. (2010). Filozofia przyrody czy przyrodoznawstwa. W: M. Kuszyk-Bytniewska, A. Eukasik (red.), Filozofia przyrody wspótcześnie, 43-53. Kraków: Wydawnictwo Universitas.

Lemańska, A. (2013). Filozofia przyrody a nauki przyrodnicze. W: S. Janeczek, A. Starościc, D. Dąbek, J. Herda (red.), Dydaktyka filozofii, t. 3: Filozofia przyrody, 31-52. Lublin: Wydawnictwo KUL

Lemańska, A., Olszewski, A., Świeżyński, A., Trombik, K. (2020). Kazimierz Któsak. Kraków: Wydawnictwo Naukowe Akademii Ignatianum.

Lubański, M. (2005a). Inspiracje modelowe lubelskich protagonistów filozofii przyrody. Roczniki Filozoficzne, 53(1), 157-165.

Lubański, M. (2005b). Filozofia przyrody u podstaw myśli filozoficznej. Roczniki Filozoficzne, 53(2), 416-417.

Ługowski, W., Lisiejew, I.K. (red.). (2011). Filozofia przyrody - dzis. Warszawa: IFiS PAN.

Łukasik, A. (2010). Wprowadzenie. W: M. Kuszyk-Bytniewska, A. Eukasik (red.), Filozofia przyrody wspótcześnie, 5-26. Kraków: Wydawnictwo Universitas.

Łukomski, J. (2006). Związek filozofii przyrody z naukami przyrodniczymi w ujęciu ks. Zygmunta Hajduka. Roczniki Filozoficzne, 54(2), 143-162.

Mazurek, M. (2021). Czesław Białobrzeski - fizyk i filozof. Filozofia i nauka. Studia filozoficzne i interdyscyplinarne, 9, 357-377.

Mączka, J. (2013). Uwagi na temat przedmiotu filozofii przyrody. W: S. Janeczek, A. Starościc, D. Dąbek, J. Herda (red.), Dydaktyka filozofii, t. 3: Filozofia przyrody, 53-67. Lublin: Wydawnictwo KUL.

Mączka, J., Skoczny, W., Koleżyński, A., Polak, P., Karolczak, M., Sieńko, D., Stwarz, M. (2012). Badania nad historią filozofii przyrody i historią nauki. Zagadnienia Filozoficzne w Nauce, 50, 10-40.

Melsen, A.G. van. (1963). Filozofia przyrody. Warszawa: Instytut Wydawniczy PAX. 
Miś, A. (2003). Filozofia wspótczesne. Gtówne nurty. Warszawa: Wydawnictwo Naukowe Scholar.

Nowak, G. (2006). Komu i po co jest dziś potrzebna filozofia przyrody?. Roczniki Filozoficzne, 54(1), 302-305.

Ogurcow, A.P. (2011). Filozofia przyrody jako ontologia. W: W. Ługowski, I.K. Lisiejew (red.), Filozofia przyrody - dzis, 33-37. Warszawa: IFiS PAN.

Piątek, Z. (2005). Komu i po co potrzebna jest dziś filozofia przyrody?. Roczniki Filozoficzne, 53(2), 434-437.

Poczobut, R. (2012). Interdyscyplinarność i pojęcia pokrewne. W: A. Chmielewski, M. Dudzikowa, A. Grobler (red.), Interdyscyplinarnie o interdyscyplinarności. Między ideq a praktyka, 39-61. Warszawa: Wydawnictwo Impuls.

Polak, P. (2016). Krakowska filozofia przyrody - między XIX a XXI wiekiem. Studia z Filozofi Polskiej, 11, 175-190.

Polak, P. (2019). Philosophy in science: A name with a long intellectual tradition. Zagadnienia Filozoficzne w Nauce, 66, 251-270.

Polak, P., Mączka, J., Grygiel, W.P. (red.). (2017). Oblicza fllozofii przyrody. Kraków: Copernicus Center Press.

Roskal, Z.E. (2006). Filozofia przyrody jako żywa pamięć i tradycja. Roczniki Filozoficzne, 54(1), 312-315.

Roskal, Z.E. (red.). (2016). Encyklopedia filozofii przyrody. Lublin: Wydawnictwo KUL.

Skoczny, W. (2012). Filozofia przyrody ożywionej w OBI. Zagadnienia Filozoficzne w Nauce, 50, 41-45.

Szczuciński, A. (2006). Filozofia przyrody nie tylko dla przyrodoznawców. Roczniki Filozoficzne, 54(1), 334-337.

Szydłowski, M. (2006). Stawianie i rozwiązywanie problemów filozoficznych w powiązaniu z naukami przyrodniczymi. Roczniki Filozoficzne, 54(1), 310-311.

Śleziński, K. (2016). Między logiką a przyrodoznawstwem i metafizyką. Obszar badań Zygmunta Zawirskiego. Studia z Filozofii Polskiej, 11, 57-72.

Świeżyński, A. (2012). Filozofia cudu. W poszukiwaniu adekwatnej koncepcji zdarzenia cudownego. Warszawa: Wydawnictwo UKSW.

Świeżyński, A. (red.). (2009). Philosophy of Nature Today. Warszawa: Wydawnictwo UKSW.

Trombik, K. (2018). Koncepcja uprawiania filozofii przyrody w ujęciu Tadeusza Wojciechowskiego - próba rekonstrukcji historyczno-filozoficznej. Roczniki Filozoficzne, 66(1), 133-152. 
Wielewska-Baka, M. (2020). Projekt interdyskursu. O tekstowym przekraczaniu granic między naukami w twórczości Michata Hellera. Gdańsk: Wydawnictwo Uniwersytetu Gdańskiego.

Wojtysiak, J. (2015). Jak to jest być filozofem, czyli o filozofach i filozofii. Ethos, 28(4), 19-39.

Wróbel, S. (2014). Interdyscyplinarnośc jako efekt dyscyplinarności. W: J. Kurczewska, M. Lejzerowicz (red.), Gtosy w sprawie interdyscyplinarności. Socjologowie, filozofowie i inni o pojęciach, podejsciach $i$ swych doswiadczeniach, 13-34. Warszawa: IFiS PAN.

Zon, J. (2005). Wprowadzenie. Roczniki Filozoficzne, 53(2), 405-407.

\title{
CONTEMPORARY PHILOSOPHY OF NATURE: A SEARCH FOR IDENTITY
}

\begin{abstract}
This article addresses the issue of the identity of the philosophy of nature in the context of three features characteristic of this philosophical discipline, namely its methodological diversity, interdisciplinarity and specific developmental dynamics. This paper examines the threats to the identity of the philosophy of nature resulting from this set of features, particularly from its methodological diversity. It will also attempt to consider these features as (paradoxically) strengthening the identity of the philosophy of nature. Lastly, the entire discussion will be considered in relation to the metaphilosophical dimension of philosophy as an area of knowledge.
\end{abstract}

Keywords: philosophy; philosophy of nature; metaphilosophy; methodology; interdisciplinarity

JAROSŁAW MACIEJ JANOWSKI

Akademia Pedagogiki Specjalnej im. Marii Grzegorzewskiej, Instytut Filozofii i Socjologii

(The Maria Grzegorzewska University, Institute of Philosophy and Sociology, Poland)

ORCID https://orcid.org/0000-0002-9712-5381

jaroslaw.maciej.janowski@gmail.com

DOI 10.21697/spch.2021.57.A.10

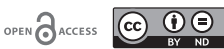

Tekst jest udostępniany na zasadach licencji Creative Commons (CC BY-ND 4.0 Międzynarodowe).

Zgłoszono: 13/08/2021. Zrecenzowano: 06/09/2021. Zaakceptowano do publikacji: 14/10/2021. 